\title{
Begging Phenomenon in Jordan: Family Role and Causes
}

\author{
Taghreed Salsi Ali Al-Muhareb ${ }^{1} \&$ Mohammad Sayel Alzyoud $^{2}$ \\ ${ }^{1} \mathrm{PhD}$ Candidate in Educational Foundations, School of Education, The University of Jordan, Amman \\ ${ }^{2}$ Associate Professor of Educational Foundations, School of Education, The University of Jordan, Amman \\ Correspondence: Mohammad Sayel Alzyoud, Associate Professor of Educational Foundations, School of \\ Education, The University of Jordan, Amman, Jordan. Tel: 962-777-111450, 962-799-039-868. E-mail: \\ Mohammad.alzyoud@outlook.com, qussaikaka@yahoo.com
}

Received: January 27, 2018

Accepted: February 8, 2018

Online Published: March 20, 2018

doi:10.5539/mas.v12n4p57

URL: https://doi.org/10.5539/mas.v12n4p57

\begin{abstract}
The study aimed to find out the role of the family in facing begging phenomena and its causes from the point of view of Jordan Families. The study population consisted of 865339 families from Amman, the Capital of Jordan. The study sample was chosen randomly, and it consisted of 4750 families. The study used a questionnaire to collect its data. To answer the first and third questions, means and standard deviations for each item and the whole domain were calculated. To answer the second question, the means, standard deviations, t-test, and one way ANOVA Analysis were used. The study revealed that some families encourage their kids to beg and seek help from others. In addition, families are busy with other responsibilities and they do not give their kids the required support that educate them and keep them away from begging. Also, there are multiple reasons that have stood behind the wide spread of the begging phenomenon such as the current difficult situation that Jordan society experience due to economic, social, and political conditions. The study revealed that low level of education for mothers is not behind the begging phenomena, but rather it is the family income at first. Unemployment reduces family income which makes the individuals to search for other means of satisfying the family needs. This, however, finally result to begging.
\end{abstract}

Keywords: Jordan, Begging phenomenon, family

\section{Introduction and Background}

Many societies are suffering from social problems that form real challenge to their stability and continuity. The main problems are unemployment, poverty, rise in crime ratios, family disintegration, divorce, and the violation of human freedom and rights. This is because of the rapid and huge changes that took place in many societies. One of the social problems which constitute a difficult challenge to the societies is the begging problem which was quite simple and hidden. However, it developed and became dangerous to the societies, threatening their security and stability. Also, it reflects negative effects on them by harming the general social landscape, and works on distorting its civilization.

The begging phenomenon is considered to be very old and prevailing in most societies despite the differences between the nations, either at the economic level or at the social and cultural level. Also, it differs according to time and place where it has been practiced in light of the continuous changes and challenges.

Most people believe that begging is a new phenomenon. However, through the old nations, cultures, it became clear that begging was one of the widespread phenomenons in those old societies. In addition, beggars employ the methods and tricks of cheating and counterfeiting in a bid to receive money.

It is noticed that the majorly used methods based on the phenomenon were by knocking doors for bread or food, or standing in front of graves in the pursue for livelihood (Jamal, 1989). Basically, the spread of the begging phenomenon is attributed to the financial return gotten by the one who makes it his/her career. Thus, the act of begging is common among the age categories ranging from the youth, women, and children. As a result, this has encouraged many of the poor to make begging as an official career, especially since it is considered the fastest means for enrichment and it also grants the one who practices it the money without working for it (Kafkafi, 2006).

The begging phenomenon is considered one of the social problems generally spreading worldwide. This can be 
seen in the Arab countries and, most especially, in the Jordanian society. The Jordanian statistical data from the Ministry of Social Development indicates that the number of the arrested Juveniles in year 2012-2013 increased from 2097 to 3896 beggars; in year 2015, the number of the arrested reached 4074; and their number increased in year 2016 to reach 6223 beggars (Ministry of Social Development, 2016).

The Jordanian society, like any other societies, is suffering from humanitarian social problems, like family disintegration and unemployment which have led to the noticeable spread of the begging phenomenon in light of the rapid increase in life requirements and needs. The begging phenomenon has become dangerous to the Jordanian society. Therefore, it is threatening its security, reliability and its development plans, distorting its civilization and touristic features, and it is also impeding its progress and prosperity. Hence, its reflections are dangerous to the society as a whole.

The begging phenomenon did not only spring out from poverty and human needs, but rather it passes these boarders to become a form of trade; thus, there are multiple forms of begging in Jordan (Al-moor, 2002). The Ministry of Social Development is working and cooperating with the General Security Directorate in order to arrest beggars or alleviate the severity of the begging phenomenon through extensive campaigns against beggars (Anabtawi, 2004). They are working to execute many programs to counter-attack begging in the Jordanian society through special committees which aim at improving families living conditions or the Juveniles conditions. This can be achieved by providing the financial support they need. Also, this would prevent families from pushing their sons to practice begging leading to the preservation of the social synthesis in the Kingdom in a bid to eliminate this phenomenon in the society (Al-Weqfi, 2010).

Statistics of Ministry of Social Development indicate that the number of beggars in year 1996 was 613 ; in the year 2016, it reached 6223 beggars, and most of the cases are concentrated in the capital, Irbid, Al-Zarqa and Madaba (Ministry of Development, 2013). In spite of all the attempts to reduce the begging phenomenon, it is still noticeably spreading. This is due to the weak role played by the family, the school, and other social upbringing institutions in providing advices and guidance. They have also failed in illustrating the extent of danger of the spread of this phenomenon on the youth and children, and on the security and reliability of the society. This is in addition to the absence of the role the media plays in spreading the awareness and enhancing the youth's role to perform their work so as to limit the phenomenon.

Consequently, the consequences of street begging are abusive languages from the public, harassments from municipal officials and police, harassment from fellow beggars, sun burn and cold during the nights, and abuse (Baltazar, 2014). Therefore, countering the begging problem requires a collective effort from the different educational and social institutions. At the top of them is the family because of the significant role the family plays in educating the individuals, caring about them, and satisfying their basic needs by providing them food, cloths, health, education, and warmth (Abu-Al-Ma'ti, 2003).

\section{Research Problem and Questions}

Jordan society is witnessing an increase of the begging phenomenon despite all the efforts exerted by the concerned parties. This phenomenon is considered as an un-civilized practice and is inconsistent with the Jordanian society ethics, traditions, and customs. Jordan is concerned about the long-term negative impact on the rising number of beggars on the streets. Beggars, including refugees, as young as six years of age, can be found begging at various traffic intersections in the capital, Amman. Hence, the public is torn between wanting to do something, but they are uncertain if helping them is the right thing to do. According to the latest statistics from the Ministry of Social Development, about 79\% of the country's street beggars are in Amman with 2,945 beggars apprehended this year compared to 1,116 in 2015 and 400 during the same period in 2014 (Nahhas, 2016). In this situation, this study aims to answer the following questions:

Question 1: What is the role of the family in facing the begging phenomenon from the point of view of the family (mother or father)?

Question 2: Are there significant statistical differences at $\alpha=0.01$ based on the role of the family in facing begging phenomenon from the point of view of the family (mother or father) due to the family income, family size, and family place of residence?

Question 3: What are the effects of the begging phenomenon in the Jordanian society from the point of view of the family (mother or father)?

Question 4: What is the importance of the causes of the begging phenomenon in the Jordanian society from the point of view of the family (mother or father)? 


\section{Importance of the Study}

This study has great importance for the following reasons:

- Enhancing the role of the Ministry of Social Development by setting a national strategy for dealing with the begging phenomenon, and its negative economic, social, security and political dimensions. This is done through a methodological way with continuous steps to know the reality of the phenomenon to touch and feel the required needs. This is done so as to confront it by activating the work and by planning to confront the phenomenon for the society in order to get rid of its negative and harmful effects. This will require Joint efforts from the concerned parties, recruiting the needed human and financial capabilities as much as possible in order to eliminate the phenomenon through the available capabilities in the Ministry.

- Enhancing the family, its coherence, and protecting the sons from the dangerous behaviors that contradict the society's values, and providing the parents with the needed methods for the appropriate upbringing of the good generation for the society.

- It might help the society individuals by cooperating with the concerned parties to rehabilitate and train the beggars to guarantee their involvement in the society, and enroll those who are uneducated into compulsory education and vocational training programs.

- Developing the awareness and perceptions of the beggars' families about the nature of dangers correlating with the presence of their sons in the streets, and the problems faced by the beggars in taking care of their sons and in protecting them through revealing its negative effects on the family and on the society.

\section{Limitations of the Study}

- Human Limitations: This study included the study sample's individuals, the families in Amman, which is the Capital of Jordan.

- $\quad$ Time Limitations: This study has been applied during the first academic term 2017-2018.

- Place Limitations: This study is limited to the Capital, Amman.

\section{Terms of the Study}

The study included the following terms:

- Family: The first educational institution in which the individual is educated to control the behavior that formed his personality, and works to organize the individuals' behavior and the determined social roles according to the cultural and civilization mode (Oqlah, 2003).

- Begging: Begging refers to the act whereby a person asking financial help from pedestrians, shops, or public places, or pretending in performing a service to others, or performing the work in disguise with the aim of begging at the streets, near the mosque and the houses, and exploiting the disability (Ismaeel, 2013).

- The Beggar: The beggar is the one who receives the money without a work that deserves it; he stands at the public places, directly or indirectly, begging such that he becomes idle because he is unproductive (Abu Al-Ma'ati, 2006).

\section{The Methodology of the Study}

This study used the descriptive analytical method using a questionnaire as the study tool to achieve its goals.

\subsection{The Study Population}

The study population consisted of all the Jordanian families in Amman, the Capital of Jordan, during the first semester 2017/2018. Their number reached 865339 families according to statistics of the General Statistics Department (General Statistics Report, 2016).

\subsection{The Study Sample}

The study sample is selected from the gender category of the study population. The sample was chosen following the simple random approach. However, it consisted of 4750 families as shown in Table 1 below.

Table 1. Distribution of the sample of the study according to their variables

\begin{tabular}{crrr}
\hline Variable & Category & $=$ N)Frequency & Percent\% \\
& & $\mathbf{4 7 5 0}$ & \\
\hline Gender & Male (father) & 2852 & 60.0 \\
\hline
\end{tabular}




\begin{tabular}{rrrr}
\hline & Female (mother) & 1898 & 40.0 \\
\hline Place of residence & City & 3950 & 83.2 \\
\cline { 2 - 4 } & Village & 642 & 13.5 \\
\cline { 2 - 4 } & Camp & 158 & 3.3 \\
\hline Family size & less than 5 & 65.0 \\
\cline { 2 - 4 } & $5-10$ & 1333 & 28.1 \\
\cline { 2 - 4 } & Above 10 & 6.9 \\
\hline Economic status & Less than 500 dinars & 2031 & 42.8 \\
\cline { 2 - 4 } & $500-1000$ dinars & 2051 & 43.2 \\
\cline { 2 - 4 } & Above 1000 dinars & 668 & 14.1 \\
\hline Total & 4750 & $100 \%$ \\
\hline
\end{tabular}

\subsection{The Study Questionnaire}

A questionnaire has been developed by the researchers to collect the data. This depends on the literature relating to the study and also on the previous studies to build the questionnaire for the current study, such as the study of Pamilia (2014) and Rico (2009). The questionnaire is designed according to Likert five point scale, and it consisted of 57 items distributed to three domain. The first dimension is the family's educational role in facing the begging phenomenon and it included 20 items, the second dimension is the effects of the begging phenomenon and it included 13 items, and the third dimension is the causes of the begging phenomenon and it included 24 items.

\subsection{Validity of the Questionnaire}

Content validity is confirmed through introducing the questionnaire in its initial form to a group of reviewers with experience and specialty. However, they were up to 15 reviewers who are professors at the University of Jordan and Al-Balqa Applied University. They determined the extent of the items' relevance, the linguistic working relevance of the items, their need for modification or changes, and the extent of the questionnaire's ability to treat the study problem in a way to achieve its goals. Therefore, the number of final items became 57 items.

\subsection{Reliability of the Questionnaire}

The internal consistency is calculated for a pilot sample of 45 male and female beggars, as shown in Table 2 below.

Table 2. The correlation coefficients of the internal consistency of the questionnaire items with the domain they belong to and with the total degree of the questionnaire

\begin{tabular}{|c|c|c|c|c|c|c|c|c|c|}
\hline \multicolumn{2}{|c|}{$\begin{array}{l}\text { Role of the family } \\
\text { phenomenon }\end{array}$} & $\begin{array}{l}\text { in facing } \\
\text { Number }\end{array}$ & the begging & \multicolumn{2}{|c|}{$\begin{array}{l}\text { The effects of the } \\
\text { begging phenomenon }\end{array}$} & \multicolumn{3}{|c|}{ Causes of the begging phenomenon } & \multirow[b]{2}{*}{$\begin{array}{l}\text { Correlation } \\
\text { coefficient }\end{array}$} \\
\hline $\begin{array}{l}\text { Number } \\
\text { of item }\end{array}$ & $\begin{array}{l}\text { Correlation } \\
\text { coefficient }\end{array}$ & $\begin{array}{l}\text { Number } \\
\text { of item }\end{array}$ & $\begin{array}{l}\text { Correlation } \\
\text { coefficient }\end{array}$ & $\begin{array}{l}\text { Number } \\
\text { of item }\end{array}$ & $\begin{array}{l}\text { Correlation } \\
\text { coefficient }\end{array}$ & $\begin{array}{l}\text { Number } \\
\text { of item }\end{array}$ & $\begin{array}{l}\text { Correlation } \\
\text { coefficient }\end{array}$ & $\begin{array}{l}\text { Number } \\
\text { of item }\end{array}$ & \\
\hline 1 & $0.543 * *$ & 14 & $0.439 * *$ & 21 & $0.414 * *$ & 34 & $0.714 * *$ & 47 & $0.419 * *$ \\
\hline 2 & $0.323 * *$ & 15 & $0.852 * *$ & 22 & $0.409 * *$ & 35 & $0.699 * *$ & 48 & $0.719 * *$ \\
\hline 3 & $0.317 * *$ & 16 & $0.741^{* *}$ & 23 & $0.401 * *$ & 36 & $0.622 * *$ & 49 & $0.684 * *$ \\
\hline 4 & $0.629 * *$ & 17 & $0.519^{* *}$ & 24 & $0.652 * *$ & 37 & $0.607 * *$ & 50 & $0.675^{* *}$ \\
\hline 5 & $0.633 * *$ & 18 & $0.562 * *$ & 25 & $0.417 * *$ & 38 & $0.603 * *$ & 51 & $0.683 * *$ \\
\hline 6 & $0.638 * *$ & 19 & $0.808^{* *}$ & 26 & $0.573 * *$ & 39 & $0.590 * *$ & 52 & $0.428 * *$ \\
\hline 7 & $0.609 * *$ & 20 & $0.670 * *$ & 27 & $0.407 * *$ & 40 & $0.651 * *$ & 53 & $0.546 * *$ \\
\hline 8 & $0.737 * *$ & & & 28 & $0.672 * *$ & 41 & $0.647 * *$ & 54 & $0.752 * *$ \\
\hline 9 & $0.715^{* *}$ & & & 29 & $0.504 * *$ & 42 & $0.632 * *$ & 55 & $0.607 * *$ \\
\hline 10 & $0.666^{* *}$ & & & 30 & $0.598 * *$ & 43 & $0.660 * *$ & 56 & $0.639 * *$ \\
\hline 11 & $0.447 * *$ & & & 31 & $0.454 * *$ & 44 & $0.725 * *$ & 57 & $0.819^{* *}$ \\
\hline 12 & $0.582 * *$ & & & 32 & $0.607 * *$ & 45 & $0.627 * *$ & & \\
\hline 13 & $0.687 * *$ & & & 33 & $0.707 * *$ & 46 & $0.693 * *$ & & \\
\hline
\end{tabular}

$\left.{ }^{*}\right)$ Significance at significance level $(\alpha=0.05)$. 
Table 2 shows that the value of the correlation coefficient for the items of the three domains (Role of the family in facing the begging phenomenon, the effects of the begging phenomenon, and causes of the begging phenomenon) with the total domain were statistically significant at the level $(\mathrm{a}=0.01)$. This, therefore, indicates the presence of internal consistency of the study questionnaire items, and that the questionnaire enjoys relevant significances for the purposes of this study. Also, the study questionnaire reliability is confirmed based on its three domains and on the total domain by applying Cronbach Alpha Approach to a pilot sample as shown in Table 2 .

Table 3. Values of study questionnaire reliability coefficients according to Cronbach Alpha Approach

\begin{tabular}{lllll}
\hline No. & The Domain & $\begin{array}{l}\text { Number of } \\
\text { Items }\end{array}$ & $\begin{array}{l}\text { Reliability } \\
\text { (Alpha) }\end{array}$ & coefficient \\
\hline $1-\quad \begin{array}{l}\text { Role of the family in facing the begging } \\
\text { phenomenon }\end{array}$ & 20 & 0.781 \\
$2-\quad \begin{array}{l}\text { The effects of the begging phenomenon } \\
\text { 3- Causes of the begging phenomenon }\end{array}$ & 13 & 0.879 \\
\hline
\end{tabular}

Table 3 indicates that the reliability coefficient for the domain "The effects of the begging phenomenon" reached 0.879 , the domain "causes of the begging phenomenon" reached 0.832 , and the third domain "Role of the family in facing begging phenomenon" reached 0.781 . Also, the total reliability coefficient for the three domains together reached 0.913. All the mentioned values consider acceptable values from the statistical side for the purpose of conducting the study.

\subsection{Correcting the Questionnaire}

The questionnaire in its final form consisted of 57 items. According to Likert five point scale with degrees ranging from 1 to 5 , it represents the following response in facing the begging phenomenon: at a very high degree $=5$, High degree $=4$, medium degree $=3$, weak degree $=2$, and very weak degree $=1$. To ascertain the role of the parent (mother or father) in facing the begging phenomenon, the effects of the begging phenomenon and the importance of the causes of the begging phenomenon, as determined regarding the means of the study questionnaire, are as follow:

Length of the Item $=$ The Higher Limit- The Low Limit. Since 3 is the number of the levels (low, medium, high). It is given as $3 / 5-1=3 / 4=1.33$. Therefore, the Judgment criteria is explained in Table 4 as shown below.

Table 4. Mean and criteria of the role of the parent (mother or father) in facing the begging phenomenon, the effects of the begging phenomenon, and the importance of the causes of the begging phenomenon

\begin{tabular}{ll}
\hline Mean & Criteria \\
\hline 3.68 & High \\
$2.34+1.33=3.6$ & Medium \\
$1+1.33=2.33$ & Low \\
\hline
\end{tabular}

\section{Findings and Discussion}

To answer the first, third and fourth questions, means and standard deviations for each item and the whole domain were calculated. To answer the second question, the means, standard deviations, t-test, and one way ANOVA Analysis were used.

Findings and Discussion of Question 1: What is the role of the family in facing the begging phenomenon from the point of view of the family (mother or father)?

Means and standard deviations, the rank, and the role were calculated on the responses of the parent of the families based on each item of the domain, and the whole domain as shown in Table 5 below. 
Table 5. Means and standard deviations, the rank, and the role about the responses of the parent of the families based on each item of the domain, and the whole domain

\begin{tabular}{|c|c|c|c|c|c|}
\hline Number & Item & Mean & S.D & Rank & Role \\
\hline 14 & The Jordanian families help the young beggars & 4.442 & 0.7290 & 1 & High \\
\hline 11 & $\begin{array}{l}\text { The presence of good example in the sons } \\
\text { keeps them from practicing begging }\end{array}$ & 4.388 & 0.7320 & 2 & High \\
\hline 1 & $\begin{array}{l}\text { The family makes the basic needs for their sons } \\
\text { available to protect them from begging }\end{array}$ & 3.882 & 0.8560 & 3 & High \\
\hline 17 & $\begin{array}{l}\text { The family cares about guiding their sons } \\
\text { towards the selection of good friends }\end{array}$ & 3.526 & 0.6330 & 4 & Medium \\
\hline 18 & The family helps the elderly beggars & 3.351 & 0.6920 & 5 & Medium \\
\hline 20 & $\begin{array}{l}\text { The family cares about their sons education to } \\
\text { the highest level }\end{array}$ & 3.117 & 0.6550 & 6 & Medium \\
\hline 9 & $\begin{array}{l}\text { The family provides the financial requirements } \\
\text { to their sons }\end{array}$ & 2.959 & 0.7750 & 7 & Medium \\
\hline 19 & $\begin{array}{l}\text { The family implants in their sons the } \\
\text { satisfaction with livelihood }\end{array}$ & 2.954 & 0.6310 & 8 & Medium \\
\hline 16 & $\begin{array}{l}\text { The family cares about monitoring and } \\
\text { following up their sons continuously }\end{array}$ & 2.954 & 0.7740 & 9 & Medium \\
\hline 15 & $\begin{array}{l}\text { The family follows their sons in studying as a } \\
\text { continuous form }\end{array}$ & 2.844 & 0.6470 & 10 & Medium \\
\hline 8 & $\begin{array}{l}\text { The family implants in their sons the love for } \\
\text { work and self- dependence }\end{array}$ & 2.739 & 0.8520 & 11 & Medium \\
\hline 10 & $\begin{array}{l}\text { The family performs their basic function } \\
\text { represented through their social education and } \\
\text { upbringing }\end{array}$ & 2.583 & 0.7880 & 12 & Medium \\
\hline 6 & The Jordanian family fights begging & 2.581 & 0.7860 & 13 & Medium \\
\hline 13 & $\begin{array}{l}\text { The parents perform their duties and bear their } \\
\text { sons responsibility appropriately }\end{array}$ & 2.538 & 0.696 & 14 & Medium \\
\hline 7 & $\begin{array}{l}\text { The family practices its authority to protect } \\
\text { their sons from begging }\end{array}$ & 2.525 & 0.6290 & 15 & Medium \\
\hline 5 & $\begin{array}{l}\text { The family provides love and intimacy to their } \\
\text { sons and daughters }\end{array}$ & 2.485 & 0.5930 & 16 & Medium \\
\hline 4 & $\begin{array}{l}\text { The family cares about its sons and daughters } \\
\text { rights (for education and health) }\end{array}$ & 2.411 & 0.7610 & 17 & Medium \\
\hline 12 & $\begin{array}{l}\text { The family cares about passing its conflicts } \\
\text { through the appropriate educational methods }\end{array}$ & 2.069 & 0.660 & 18 & Low \\
\hline 2 & $\begin{array}{l}\text { The family implants in their sons the } \\
\text { satisfaction with the livelihood }\end{array}$ & 1.782 & 0.8820 & 19 & Low \\
\hline 3 & $\begin{array}{l}\text { The family cares about the enlightenment of } \\
\text { their sons regarding begging risks }\end{array}$ & 1.690 & 0.8440 & 20 & Low \\
\hline Total & & 2.891 & 0.725 & & Medium \\
\hline
\end{tabular}

Table 5 explained that the total role came at a medium role with a medium degree for the total domain. Since the mean reached 2.891 with a standard deviation of 0.725 at high degree, this shows that some families encourage their kids to beg and seek help from others. In addition, other families are busy with other responsibilities and they do not give their kids the required support that educate them and keep them away from such uncivilized practices.

It is noticed from Table 5 that item 14 came at the first rank, with mean of 4.442 and a standard deviation of 0.729 at a high degree. This, however, is attributed to the responses and the provision of help by the citizens to the young people who are begging regardless of their need for begging, which encourages them to turn begging into a career. This confirms that the Jordanian families need enlightenment about the begging risks, and there is a necessity to set strict and deterring laws to prevent families from encouraging their sons to go out to beg. However, this will lead to danger based on the findings of the society. Followed by the items $(1,11)$, it came at high degree and received the second and the third ranks with the means $(3.882,4.388)$ and standard deviations 
$(0.8560,0.732)$. Thus, this is attributed to the importance of the presence of good example in the Jordanian families which is characterized by praiseworthy ethics and work to encourage the individuals to follow it. Thus, this is in addition to the efforts of the head of family to provide his son with all the basic needs and requirements, including education, heath, food, and cloths. The provision of these basic needs would help to limit the spread of the begging phenomenon and in reducing the number of beggars on the streets.

Followed by item (17) with the mean (3.526) and standard deviation (0.633), the fourth rank indicates a medium role. Thus, this is attributed to the importance of the Jordanian commitment to the appropriate values and ethics in limiting begging. Followed by item (18) which occupied the fifth rank with the medium (3.251) and standard deviation (0.692) which indicates at a medium degree, this is attributed to the people's feeling that begging of this category is due to the weak, deficit, and lack of the one who support them. Item (16), which came at the sixth rank with mean (3.117) and standard deviation (0.655), indicates the medium role. Thus, this is attributed to low level of social awareness about the importance of education and the available relevant educational care for the sons to protect them from poverty and in asking people for their need. Nevertheless, Reiko et al. (2009) agrees with the findings of the study.

Findings and Discussion of Question 2: Are there significant statistical differences at $\alpha=0.05$ based on the role of the family in facing begging phenomenon from the point of view of the family (mother or father) due to the family income, family size, and family place of residence?

In answering question two, the means, standard deviations, t-test, and one way ANOVA analysis were used as shown in Table 3, 4, 5, and 6.

Table 6. The means and standard deviations of the role of the family in facing begging phenomenon from the point of view of the parent (mother or father) of the family due to the family income

\begin{tabular}{lllll}
\hline Role of the Family & Family income & Sample size & The mean & Standard deviation \\
\hline $\begin{array}{l}\text { Role of the family in facing } \\
\text { the begging phenomenon }\end{array}$ & $\begin{array}{l}\text { Less than } \\
500\end{array}$ & 2031 & 2.904 & 0.726 \\
& $\begin{array}{l}\text { From 500- } \\
1000\end{array}$ & 2051 & 2.895 & 0.726 \\
& $\begin{array}{l}\text { More than } \\
1000\end{array}$ & 668 & 2.842 & 0.724 \\
Total & 4750 & 2.891 & 0.725 \\
\hline
\end{tabular}

Table 6 shows the means and standard deviations related to the Jordanian family estimations in facing begging phenomenon by the difference in the variable family Income. Referring to Table 6, it was shown that there were differences between the means values based on the role of the family in facing the begging phenomenon. To know the significance of the differences in the means, one way variance analysis was conducted as seen in Table 7.

Table 7. One way analysis of variance due to the family income

\begin{tabular}{lllllll}
\hline Source of the variance & $\begin{array}{l}\text { Sum of the } \\
\text { squares }\end{array}$ & $\begin{array}{l}\text { Freedom } \\
\text { degree }\end{array}$ & $\begin{array}{l}\text { Mean } \\
\text { squares }\end{array}$ & $\begin{array}{l}\text { of } \\
\text { calculated }\end{array}$ & Sig. Level \\
\hline Between the groups & 1.789 & 2 & 0.895 & 1.701 & 0.131 \\
Inside the groups & 2496.829 & 4747 & 0.526 & & \\
Total & 2498.618 & 4749 & & & \\
\hline
\end{tabular}

Table 7 indicates that there were not any statistically significant differences at the level $(a \leq 0.05)$ due to the family income. This is attributed to the fact that the role of the family in facing the begging phenomenon is the responsibility of all the families. Also, this is regardless of the income level and, as such, they are not limited to the poor families. In this context, families have the same responsibility and duty toward their members. 
Table 8 below shows the means and standard deviations of the role of the family in facing begging phenomenon from the point of view of the parent (mother or father) of the family due to the family size

Table 8 . The means and standard deviations due to the family size

\begin{tabular}{lllll}
\hline The domain & $\begin{array}{l}\text { Number of the } \\
\text { family individuals }\end{array}$ & Sample size & Mean & $\begin{array}{l}\text { Standard } \\
\text { deviation }\end{array}$ \\
\hline $\begin{array}{l}\text { Role of the family in facing the } \\
\text { begging phenomenon }\end{array}$ & $\begin{array}{l}\text { Less than } \\
500\end{array}$ & 2031 & 3.133 & 0.726 \\
& From 5 to 10 & 2051 & 2.888 & 0.726 \\
& above than & 668 & 2.162 & 0.724 \\
Total & 10 & 4750 & 2.891 & 0.725 \\
\hline
\end{tabular}

Table 8 shows that there were differences between the means values based on the role of the family in facing the begging phenomenon due to the family size. To know the significance of the differences in the means, one way analysis of variance was conducted as shown in Table 9.

Table 9. One way analysis of variance due to the family size

\begin{tabular}{lllllll}
\hline Source of the variance & $\begin{array}{l}\text { Sum of } \\
\text { squares }\end{array}$ & $\begin{array}{l}\text { the } \\
\text { degree }\end{array}$ & $\begin{array}{l}\text { Mean } \\
\text { squares }\end{array}$ & $\begin{array}{l}\text { of } \\
\text { calculated }\end{array}$ & $\begin{array}{l}\text { value } \\
\text { Sig. Level }\end{array}$ \\
\hline Between the groups & 9.062 & 2 & 4.531 & 8.640 & 0.000 \\
Inside the groups & 2489.556 & 4747 & 0.524 & & & \\
Total & 2498.618 & 4749 & & & \\
\hline
\end{tabular}

Table 9 shows that there are significant statistical differences due to the family size. Scheffe test was used to find out the source of the differences as shown in Table 10.

Table 10. Results of Scheffe test for the post-comparison between the means in the responses of the study sample towards the family role in facing begging

\begin{tabular}{|c|c|c|c|c|c|}
\hline The domain & $\begin{array}{l}\text { Number of the family } \\
\text { members }\end{array}$ & Mean & Less than 5 & $5-10$ & More than 10 \\
\hline \multirow{3}{*}{$\begin{array}{l}\text { Role of the family in } \\
\text { facing the begging } \\
\text { phenomenon }\end{array}$} & Less than 5 & 3.1331 & & & \\
\hline & $5-10$ & 2.880 & 0.2451 & & \\
\hline & More than 10 & 2.1621 & 0.9710 & 0.7259 & \\
\hline
\end{tabular}

Table 10 shows that there are statistically significant differences $(a \leq 0.05)$ due to the family size. The differences were in favor of the families that have less than five members. This is because families that are less than five members are able to follow up and monitor their kids and guide them in the right direction, while large families are unable to do the same.

Table 11 shows the means and standard deviations of the role of the family in facing begging phenomenon from the point of view of the parent (mother or father) of the family due to the family place of residence 
Table 11. The means and standard deviations due to the family place of residence

\begin{tabular}{|c|c|c|c|c|c|}
\hline The domain & $\begin{array}{l}\text { Place } \\
\text { residence }\end{array}$ & of & Sample size & Mean & $\begin{array}{l}\text { Standard } \\
\text { deviation }\end{array}$ \\
\hline \multirow{3}{*}{$\begin{array}{l}\text { Role of the family in facing the } \\
\text { begging phenomenon }\end{array}$} & City & & 3087 & 3.007 & 0.720 \\
\hline & Village & & 1333 & 2.323 & 0.727 \\
\hline & Camp & & 330 & 2.296 & 0.723 \\
\hline
\end{tabular}

Table 11 shows that there were significant statistical differences $(a \leq 0.05)$ in the study sample response regarding the role of the family in facing begging phenomenon due the family place of residence.To know the significance of the differences in the means, one way analysis of variance was conducted as seen in Table 12 below.

Table 12. One way analysis of variance due to the family residence

\begin{tabular}{|c|c|c|c|c|c|}
\hline Source of the variance & $\begin{array}{l}\text { Sum of the } \\
\text { squares }\end{array}$ & $\begin{array}{l}\text { Freedom } \\
\text { degree }\end{array}$ & $\begin{array}{l}\text { Mean of } \\
\text { squares }\end{array}$ & $\begin{array}{l}\text { (F) value } \\
\text { calculated }\end{array}$ & Sig. Level \\
\hline Between the groups & 5.672 & 2 & 2.836 & 5.400 & 0.000 \\
\hline Inside the groups & 2492.946 & 4747 & 0.525 & & \\
\hline Total & 2498.618 & 4749 & & & \\
\hline
\end{tabular}

The one way analysis of variance results, as shown in Table 12, indicated that there are significant statistical differences due to the family residence. Scheffe test was used to find out the source of the differences as shown in Table 13.

Table 13. Results of Scheffe test for the post-comparison between the means in the responses of the study sample towards the family role in facing the begging due to place of residence

\begin{tabular}{lll}
\hline The domain & $\begin{array}{l}\text { Place } \\
\text { residence }\end{array}$ & of \\
\hline $\begin{array}{l}\text { Role of the family in facing } \\
\text { begging phenomenon }\end{array}$ & City & 3.0068 \\
& Village & 2.3225 \\
& Camp & 2.2963 \\
\hline
\end{tabular}

Scheffe results, as shown in Table 13, indicated that there were statistically significance differences $(a \leq 0.05)$ in the study sample response due to the place of residence, in favor of the Urban residents. This is attributed to the limited social relationships and weak social coherence in cities. However, the role of the family will be limited in contrast with the villages and camps residents in which social coherence is prevailing between the individuals, as the circle of the relationships expands in the village and the camps.

Findings and Discussion of Question 3: What are the causes of the begging phenomenon in the Jordanian society?

In answering question 3, means, standard deviations, the ranks, and the importance of the causes of the begging phenomenon in the Jordanian society were calculated to obtain the responses of the study sample individuals as shown in Table 14.

Table 14. Means, standard deviations and the rank

\begin{tabular}{lllll}
\hline No. & Item & Mean & S.D & Rank \\
\hline 53 & $\begin{array}{l}\text { Behind the begging phenomenon stands the lack of } \\
\text { available family basic needs for their sons }\end{array}$ & & 0.416 & 1 \\
36 & Weak begging confrontation increases the begging 4.624 & 0.484 & 2 \\
\hline
\end{tabular}


phenomenon

Practicing the begging using the push's earning by simple and illegal ways

Poor families push their sons into begging profitable profession which leads to increase in the begging phenomenon

The insufficient role of the mosques in facing the begging phenomenon financial need awareness about begging risks phenomenon refugees

Poverty stands behind the begging phenomenon

Weak ethical and religious stimuli in the individuals leads

to illegal earnings phenomenon

Implementing the begging confrontation programs

needing individuals phenomenon

Default of the
phenomenon phenomenon

Low level of phenomenon

\section{Divorce stands behind the begging phenomenon}

Violence by the family contributes to their sons begging

Providing care for those with special needs limits the begging phenomenon

Low level of the mother education stands behind the begging phenomenon Unemployment contributes to the increase of the begging

4.623

4.462

4.456

4.419

Some individuals practice the begging without the

The multiple media means deficit in spreading the

Absence of social justice leads to increase in the begging

The number of the beggars increases by the flow of

4.415

0.739

4.379

0.788

8

4.307

0.727

12

4.171

0.715

13

Expensive living costs stands behind the begging

4.057

0.649

14

Negligence of Ministry of Social Development in 3.768

0.827

15

Failure of the charitable association in helping the 3.569

0.572

16

Low income leads to the increase of the begging 4.501

0.669

17

Family disintegration stands behind the begging 3.364

0.726

18

0.766

19

3.226

0.642

20

$3.063 \quad 0.648$

21

2.797

0.742

22

2.464

1.170

23

1.793

0.761

24

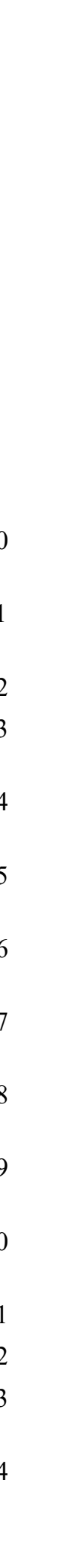

Table 14 showed the rank of the causes of the begging phenomenon based on the mean for each item. The highest mean value reached 3.996 with a standard deviation of 0.683 . This is attributed to the multiple reasons that stand behind the spread of the begging phenomenon in the light of the current situations that Jordan society experience due to economic, social, and political conditions. 
Item (53) which states "behind the begging phenomenon stands the family inability to provide the basic needs to their sons" came at the first rank with a mean of 4.785 and a standard deviation of 0.416 . This is referred to the belief of the Jordan families that the economic conditions are the main reasons behind the Begging phenomena in Jordan. This is because many families live in difficult conditions that prevented them from meeting their basic needs. This is majorly seen in large families and families with physical and mental disabilities.

Item (37) which stated "Weak begging confrontation increases the begging phenomenon" came at the third rank with means (4.623) and standard deviation (0.485). This is attributed to the desire to receive financial income by simple ways without effort. However, this is because the beggars see the begging career to be very profitable.

Item (42) which states "Unemployment contributes to the increase of the begging phenomenon" came at the fourth rank with mean (4.462) and standard deviation (0.718). This is attributed to the fact that unemployment reduces the family income level which makes individuals to search for other means to satisfy the family needs which might lead to begging.

Item (41) which stated "Poor families push their sons into begging" came at the fifth rank with a mean of 4.456 and a standard deviation of 0.729 . This is attributed to the fact that beggars practiced begging due to poverty and their inability to provide their necessary needs. As a result, families push their sons into practicing begging.

Item (52) which stated that "Low level of the mother education stands behind the begging phenomenon" came at the last rank with a mean of 1.793 and a standard deviation of 0.761 . This is attributed to the fact that the level of education is not behind the begging phenomena, but rather it is the family income at the first and last place.

\section{Conclusion and Recommendations}

Some families encourage their kids to go into begging and seek help from others. In addition, families are busy with other responsibilities and they do not give their kids the required support that educates them and keep them away from such uncivilized practices. Also, there are multiple reasons that stand behind the spread of the begging phenomenon such as the current difficult situation that Jordan society experience due to economic, social, and political conditions. The study revealed that low level of education for mothers is not behind the begging phenomena, but rather it is the family income at the first and last place. Unemployment reduces the family income level which makes individuals to search for other means to satisfy their family needs which, therefore, leads to begging. The study stated that some people practice begging due to poverty and their inability to provide the necessary needs. On the other hand, others practice begging to receive financial income in simple ways without effort, since they see it as a profitable career. Finally, families with less than five members are able to follow up and monitor their kids and guide them in the right direction, while large families are unable to do the same. Therefore, beggars are from large families.

\section{In the light of the findings, the study recommends the following}

1. Provide professional training and jobs that enable beggars to support themselves and their families.

2. Provide enough financial support to the disabled and people with special needs to keep them away from practicing begging.

3. Activating the role of the begging preventing laws, sever legal procedures against the beggars, and involving all concerned parties in limiting the phenomenon.

4. Carrying out awareness campaigns through all media channels on the dangers of the begging phenomenon.

\section{References}

Abu El Maai, M. (2006). Evaluating of Social Organizations Programs, Cairo Al: Zahraa.

AbuEl Maati, M. (2003). social service in the domain of social defense, Cairo: Dar al-Zahra al-Shorouk.

Ahamdi, H. (2010). A study of beggars characteristics and attitude of people towards the phenomenon of begging in the city of Shiraz. Journal of Applied Society, 39(3), 148-150.

Al-Waqfi, S. (2010). Recitation and Jurisprudence in Islamic Jurisprudence, Thesis, Al-Bayt University, Jordan.

Anabtawi, M. (2004). Degree of the program to children begging phenomenon carried by the Ministry of Social Development in Jordan during the period 1996-2001. Unpublished Master thesis, University of Jordan, Amman, Jordan.

Badamasi, I. (2015). A case Study and prevalence Consequencesof Street Begging among Adult and Children In Nigeria. Precedes Social and Behavioral Science, 171(1), 323-333. 
Baltzar, N., \& Mgab, M. (2012). Categories of Beggars and Factors influencing Factors Influencing Street Begging In central Tanzania. The Centre for African Area Studies, 33(2),133-143.

Ismail, R. (2013). Phenomenon of begging children, conductive studies. Iraq, 1(42), 27-31.

Jamal, M. (1989). Begging and homelessness in comparative law, Cairo: Arab Thought House.

Kafkafi, A. (2001). Education and Psychiatry, Cairo: Dar Hijra for Printing and Publishing.

Kerebih, A., Tilahun, T., \& Tilahun, M. (2014). Demographic and socioeconomic determinants of women begging in Bahir Dar, Ethiopia. Humanities and Social Sciences, 2(3), 75-80.

Khan, J. (2013). Problem of Beggers: A case study. International Journal of Management and Social Sciences Research, 2(120), 67-74.

Ministry of Social Development (2012). Annual Report. http://www.mosd.gov.jo, Amman, Jordan.

Ministry of Social Development (2013). Annual Report. http://www.mosd.gov.jo, Amman, Jordan.

Ministry of Social Development (2015). Annual Report. http://www.mosd.gov.jo, Amman, Jordan.

Mour, M. (2002). Social and Economic Characteristics of beggars in Jordan. Master Thesis, University of Jordan.

Nahhas, R. (2016). Begging an alarming phenomenon in Jordan, the Arab Weekly. Retrieved from https://thearabweekly.com

Oqlah, M. (2003). The Family System in Islam, Amman: Al Resalah Library for Publishing and Distribution.

Pamel, A. (2003). The effect of chronic stress cognitive Functioning and Academic Achievement of Homeless children. Thesis PhD, Los Angelo's Albant International university. Dissertations, 64(1), 45-56.

Ramlan, M., \& Nur, D. (2014). Street Begging in Kuala Lumper. Science and Policy Studies, 78(1), 10-13.

Reiko, H. et al. (2009). Street children Needs in Mongolia College of Social work university of Utah. Global of Child Research, 12(4), 22-24.

Shehata, Z. (2001). Street children and its relation to some personal variables, unpublished master thesis, Institute of Graduate Studies, Ain Shams University, Egypt.

\section{Copyrights}

Copyright for this article is retained by the author(s), with first publication rights granted to the journal.

This is an open-access article distributed under the terms and conditions of the Creative Commons Attribution license (http://creativecommons.org/licenses/by/4.0/). 